\title{
Plant and Animal production in Montenegro with Overview of the Food Industry
}

\author{
Goran Rajović $^{1, a, ~}{ }^{,}$, Jelisavka Bulatović ${ }^{2, b}$ \\ ${ }^{1}$ Vojvode Stepe 252, Belgrade, Serbia \\ ${ }^{2}$ College of Textile Design, Technology and Management, Belgrade, Serbia \\ E-mail address: adkgoran.rajovic@gmail.com; bjelisavka.bulatovic@gmail.com \\ "Corresponding author: dkgoran.rajovic@gmail.com
}

Keywords: Montenegro, agriculture, plat production, animal production, food industry.

\begin{abstract}
The subject of this paper is to consider the causes of the condition and systematization of the main problems of agricultural development in Montenegro. Bearing in mind the structure of agricultural production, available resources and achieved the level of productivity, we estimate that the change must take place in the direction of growth, yield stabilization and production structure changes in crop production and achieving greater representation of livestock in the value of agricultural production. The future development of the agrarian sector of Montenegro should be directed towards modernizing and changing the production structure towards market orientation and improve overall efficiency. Agriculture Montenegro in its very important role, should fulfill several strategic objectives: produce sufficient amounts of safe food that will be accepted by consumers at home and abroad, provide a higher level of self-sufficiency and improve the trade balance of the country, creating value that will provide income to farmers and the gross domestic product growth magnify the overall economy of the country and to keep population in the countryside and thus contribute to the protection and promotion of these areas.
\end{abstract}

\section{INTRODUCTION}

A favorable climate for the production of different varieties of plants, well preserved natural environment, including high-quality, preserved and fertile land, the low level of pollution Thanks to the low use of fertilizers and pesticides, are elements that contribute to the development of agriculture. Climate, rich biodiversity and nature and a clean environment are excellent preconditions for the development of organic agriculture. Also available land resources are an additional advantage along with the traditional production of typical products and the use of indigenous varieties and species in several sectors. Rising domestic markets, where we can expect increased demand from the tourism sector as well as processing facilities that have been developed in several sectors are a good example of the development of new value-added products which are offered on the market [1].

After a few turbulent years (1945-1953), in which he ruled compulsory purchase of agricultural products (repealed in 1952) and when there was a (unsuccessful) attempt at collectivization of agriculture (1948-1953), the social structure in agriculture of Yugoslavia (including Montenegro) stabilized [2]. However, during seventies in last century starts intensification of agricultural production. The intention was that higher yields, especially in the social sector, often at the expense of profitability. Production on family farms is falling behind on technology and more attention was paid to the economy. Start the transition to a market economy coincided with the UN sanctions, conflicts in the former Yugoslavia and the collapse of the economy. Insulated from the world and without a developed vision of agricultural production and sales in such an environment has a social, not a development orientation, so the market short range, low investment, and thus yields. After the year 2000 starts opening according to World: tariff liberalization, the abolition of import licenses and quotas and the establishment of market economy [3]. 
In the given circumstances of agricultural Montenegro in its very important role, should fulfill several strategic goals: produce sufficient amounts of safe food that will be accepted by consumers at home and abroad, provide a higher level of self-sufficiency and improve the trade balance of the country, creating value that will provide income to farmers and the gross domestic product growth magnify the overall economy of the country and to keep population in the countryside and thus contribute to the protection and promotion of these areas [4].

\section{RESEARCH METHODOLOGY}

The farming activity based upon the application of the measures recommended for the good agro-environmental practices, has a visible impact upon sustainable rural development, which is noticed in the economic, social, ecological and historic-cultural plan, both at local and national level. The whole information volume in this article was obtained through specific methods for the selective research, respecting all its stages from the methodological point of view: identification of the researched issue, research framework delimitation, information collection, data processing, analysis and interpretation drawing up the conclusions [5]. Research also played an important role in the article, which consisted, on one hand, in the identification of other studies and articles on the same subject, and in the processing of some statistic data, on the other hand. Hence, the information sources used can be classified into governmental sources (statistic, ministerial and from research institutes), and into non-governmental sources (independent publications). As the statistical data agricultural Montenegro and its impact upon the economy, environment and human society are very few, the research results are based on a series of mainly qualitative analyses, on the one hand, and on a series of logical rationales, on the other hand [5]. In order to get an adequate picture of agriculture in Montenegro, we applied the method alternate divider in the system 6/6 Kostrovicki [6], Kostrovicki [7], Jaćimović [8], Tyszkiewicz [9]. The method of alternating divisor in system 6/6 has found the application and in the texts (see Rajović and Bulatović [10], Rajović and Bulatović[11], Rajović and Bulatović [12], Rajović and Bulatović[13], Rajović and Bulatović[14], Rajović and Bulatović [15], Rajović and Bulatović[16]) authors of this paper.

\section{ANALYSIS AND DISCUSSION}

Our research evidence based on similar studies Anufrijev and Dašić [3], indicates to basic characteristics of agricultural production in Montenegro, which are reflected through: low average yields as compared to the EU, and in comparison with the period of the eighties years the last century; a large number of small producers who produce for their own needs with minimal investment; underdeveloped market rural credit, both because of low demand, but also due to weaker supply; great variability in crop production; a drop in production of livestock products; failure to the create significant improvements in producing and selling vegetables; decline in industrial production; stagnation in milk production, but also progress in the processing of milk and reduced rate of plant and animal production in total agricultural production following the establishment of market economy (see Rajović [17], Rajović and Bulatović[18], Rajović and Bulatović[19], Rajović and Bulatović [20], Rajović and Bulatović [21], Rajović and Bulatović[22], Rajović and Bulatović [23], Rajović and Bulatović[24]).

According to Stefanović et al [4] in new, different and complex economic conditions, the domestic and international level, the role of the agro-food sector must be defined so that remains a source of livelihood the relatively poor rural population and to evolve into a more competitive sector, which could represent a significant development segment of the domestic economy, especially from the point of export. This sector has in recent decades, considered as a whole, had a quick and development are significant changes, both in quantitative and structural terms. Such direction and character trends flowed continuously for many years, with the ongoing efforts to achieve a higher level of development of this industry, which is created, and its dynamic and constant changes. This, among other things, reflected in the growing production, substitution of 
traditional manufacturing-intensive, applications of modern technological solutions, increasing exports...

According to data of the Statistical Office of Montenegro [25], of the total agricultural area of Montenegro (515.717 ha), meadows occupy 126.726 ha, area under fields and gardens 45.809 ha, area under orchards 12,028 ha, area under vineyards 4.512 ha area under ponds, ponds and reed 2.644 ha. In order to show the structure of agricultural land in Montenegro in 2012, we applied the method alternate divisor in system $6 / 6$ and determine the next direction ${ }^{1}: \mathbf{O}_{\mathbf{1}} \mathbf{L}_{\mathbf{2}} \mathbf{P}_{\mathbf{3}}$ balanced grazing direction use agricultural land with a greater share of meadows and plowed land. According to Rajović and Bulatović [24] arable areas in Montenegro in 2012 covered the surface area of 45,809 ha. Of the total sown area under grain It was 5.119 ha, under industrial plants 112 hectares, under vegetable crop gar- 19.465 hectares, or under forage crops 7.779 ha, area under uncultivated plowed fields were covered the 13.310 ha and the area under the seedlings of 2 ha. In order to get an adequate picture of the structure of arable land, and here we apply the method of alternating divisor in system $6 / 6$ and determine the next direction of use of arable land ${ }^{2}: \mathbf{P}_{\mathbf{0 2}} \mathbf{N}_{\mathbf{2}} \check{\mathbf{Z}}_{\mathbf{1}} \mathbf{S k}_{\mathbf{1}}$ direction with equal participation of vegetables, uncultivated land and participation of grain and fodder crops. "Agricultural policy is directed towards the development of agricultural production and preservation of agricultural resources Montenegro should be an essential priority within the overall development of the country, both in economic and in social and environmental terms. Bearing in mind the structure of agricultural production in Montenegro, available resources and achieved the level of productivity, we estimate that the change must take place in the direction of growth, yield stabilization and production structure changes in crop production and achieving greater representation of livestock in the value of agricultural production "[26].

According to data of the Statistical Office of Montenegro [25] sown area under maize 2012 amounted to 2.706 ha, under wheat, 773 ha under barley 710 ha. Analyzed years total yield under corn amounted to 8.719 tons, the yield per hectare of 3.2, total wheat yield under 2.151 tons, the yield per hectare of 2.8, total yield under barley 1.607 tons, the yield per hectare 2.3. Statistical Office of Montenegro (2013) does not provide data for other crops of corn 2012. Therefore, we will use the data of the Statistical Office of Montenegro from [25], as well as research Ćetković [27]. The total sown area under oats in Montenegro in 2007 amounted to 221 ha, the surface of which realized production of 240 tons, and the average yield per hectare was 1.1 tones. Other cereals (millet, buckwheat ...) cultivated in Montenegro on an area of 354 ha in 2007. However, we do not have accurate data on area and production under millet in Montenegro. Therefore, we will use the research Ćetković [27], which emphasizes that average world grain millet is around $776 \mathrm{~kg} / \mathrm{ha}$, which is a very low yield. Total sown area under buckwheat in Montenegro amounted to 8.8 ha, total yield of $9.900 \mathrm{~kg}$, the yield in $\mathrm{kg} / \mathrm{ha} 1.125$. Industrial crops are grown on 112 hectares of sown area under cereals in Montenegro in 2012. According to data of the Statistical Office of Montenegro [25] total sown area under tobacco (production only in the private farms) was 112 ha, total yield of 226 tons, the yield per hectare 2.0. Potatoes, according to official statistics are dominant vegetable crop. Under this vegetable crop was in 2012. 11.253 ha. Total return is the 132.674 tones, average yield per hectare of 11.8. The total sown area under pepper totaled 852 ha (total yield of 16.705 tons, the yield per hectare 19.6). Areas under melons and watermelons are covered the 1.455 ha (total yield of 41.976 tons, the yield per hectare of 28.8), and area under garlic 222 ha (total yield of 778 tons, the yield per hectare is 3.5), the area under cabbage and kale 1.969 ha (total yield of 46.996 tons, the yield per hectare 23.7), area under tomatoes 1.009 ha (total yield of 22.830 tons, the yield per hectare of 1.5), the area under black onion 573 ha (total yield of 3.274 tons, the yield per hectare of 5.7), the area under beans 528 ha (total yield 972 tones, yield per hectare is 1.5), area under peas 124 ha (total yield of 256 tons, the yield per hectare 2.1). For the realization of goals in the vegetable culture need to improve the national team of hand and introduce

\footnotetext{
${ }^{1}$ The variables and their symbols used in the formula: O- Arable land, V-orchards and vineyards, L- Meadows, PPastures.

${ }^{2}$ The variables and their symbols used in formulas: $\breve{Z}$ - grain, I - industrial plants, Po - Vegetables, Sk - fodder crops, Nuncultivated arable land.
} 
high-yield varieties, apply new technologies, increase the use of irrigation systems and watering, to expand production in a protected area, especially on family farms with small and controlled a large number of able-bodied members.

According to data of the Statistical Office of Montenegro [25] sown area under clover 2012 amounted to 748 ha, the total yield of 2.663 tons, the yield per hectare 3.6. In the same period, the total sown area under fodder beet was 153 ha, total yield of 1.892 tons, the yield per hectare of 12.4. Sown areas under alfalfa amounted to 3.110 ha in 2012, the total yield of 11.700 tons, and the average yield of 3.8 tons per hectare. Harvested area under maize for fodder in the period of 2012 amounted to 316 ha, the total yield of 3.482 tons, the yield per hectare of 11.0. Total harvested area of meadows amounted to 126.726 ha, the total yield of 165.871 tones, the yield per hectare 1.3. Harvested area under covered the pastures are 323. 998 ha, total yield 66838 tones, the yield per hectare 0.2. According to Gulan [28], in cultivated cropping system should introduce more forage legumes (alfalfa and clover), green peas, beans, broad beans ... In addition to increase production and improve the quality of fodder crops on arable land, planted and natural grasslands, attention should be paid to improving the technology of preparation, storage and use of food. Plant production in Montenegro should develop in the direction of: increase in the total area under arable crops, increasing the area under industrial crops, orchards, vineyards and meadows, increasing the yield per unit of capacity while reducing their variability, improving product range and assortment of production and product quality, larger market and export orientation.

Plums are the number of bearing trees and total fruit production the dominant culture. According to data of the Statistical Office of Montenegro [25] the number of bole plum in the period 2012 totaled 1.408 .130 , number of productive bole 1.191 .085 , the total yield of 8.769 tons, and the yield per tree $7.4 \mathrm{~kg}$. Number of apple trees stood at 622.495 , the number of fruit-bearing trees 519.403 total 5.712 tons, the yield per hectare of 11.0. Number of trees pears 2012 amounted to 235.999 , the number of fruit-bearing trees 205.219 Total production 2.414 tones, the yield per tree $11.8 \mathrm{~kg}$. Statistical Office of Montenegro [25] points also to other fruit culture, fruit production and average yields. Total production in 2012 was at the cherry 1.932 tones, the average yield at 15.7 $\mathrm{kg}$, peach 3.857, the average yield of 20.1, with walnut 665 tons, the average yield of 11.9. The total number of trees cherry in 2012 amounted to 144.506 (123.396 bearing trees), peach 200.507 (bearing trees 191.936), nuts 66.861 (bearing trees 55.818). Number of vines in 2012 was 17.559.891, the number of fruit-bearing trees 16.570 .705 , the total yield of 38.861 tons, the yield per vine $2.4 \mathrm{~kg}$. The fruit and grape production, it is necessary to increase the number of trees continental species of fruit, grapevines and the total area under vines. Significant increase in the yield per unit of capacity can be increased and the share of these sectors in the structure of the value of total agricultural production. Development of fruit, with large plantations in monoculture, mainly in the plain area, should focus on new plantations are located in the respective agro-ecological regions, in the mountain area of Montenegro, taking into account local environmental resources. Increasing the number of species and varieties requires improving domestic selection of certain types of continental fruits, as well as import the appropriate assortment of high production and market value (raspberries, blackberries, walnuts, hazelnuts).

Livestock production provides products for the nutrition of the local population (milk, meat, eggs) on the one hand, and for the food industry (dairies, slaughterhouses, etc.), on the other hand. Can largely to provide quality products for export, especially when it comes to cheese, from sheep and goat, standard quality and refinement label of origin. But to livestock production could provide mentioned, it is necessary to improve the current status of livestock production in Montenegro through a series of support measures from the Ministry of Agriculture.

In addition to its importance and favorable natural conditions of livestock in Montenegro is in deep crisis. This is indicated by the data of the Statistical Office of Montenegro [25] of the total number of cattle in 2012 (000) bovine animals - 84 sheep - 207, 18 - pigs, goats - 23, horses - 4, the chickens -732 , hive -43 . In order to get an adequate picture of livestock production in Montenegro and here we apply the method of alternating divisor within the system $6 / 6$ and determine the next 
direction ${ }^{3}: \mathbf{0}_{3} \mathbf{G}_{2} \mathbf{K}_{1}$ Direction with equal participation of sheep farming with higher participation bovine animals and goat participation. Total milk production in Montenegro in 2012 amounted to 159.240 (000) liters. Of which the production of cow's milk waste $145.953(000)$, 2.474 liters per cow. Production of sheep milk was 9.584 (000) liters, 70 liters per sheep. Number of slaughtered cattle in 2012 was 26.649 throat (in enterprises and cooperatives in 2012 -1956; on private farms 24.693), sheep 25.625 throat (in enterprises and cooperatives 2012-195, on private farms 2012-25.430). Pork production is dominated by family farms and has expressed a high degree of in-kind character. The total number of pigs slaughtered in 2012 was 39.470 throats (in enterprises and cooperatives 2012-13.113, on private farms 2012-26.357). According to Škorić [29], the annual production of poultry meat per capita is around 12 kilos. The rapid turnover, modest investments and small risks, the benefits are poultry production. The production of eggs in is Montenegro 2012 68.060 or 157 laying hens eggs. According to Škorić [29] in developed countries, the total consumption of eggs of two-thirds is used in the industry of pasta and confectionery industry in the production of mayonnaise and other forms of consumption, as well as intermediates, and the rest by the general public, while the egg us still used exclusively in the shell. Yet, of all branches of agriculture in Montenegro beekeeping is at this point in the expansion. According to data of the Statistical Office of Montenegro [25] Beekeeping Association of Montenegro brings together 1.650 beekeepers in 25 associations has a total of 42.680 beehives from which in 2012 achieved a total production of 532 tones of honey and $13 \mathrm{~kg}$ per hive, not counting other bee products such as wax, propels, pollen, royal jelly ... Total production of wool in Montenegro in 2012 amounted to 275 tones, the average yield of wool per sheep is around $1.5 \mathrm{~kg}$. The racial composition dominated pramenka $(80 \%)$ and quality of the wool than 32 micrometers, so that Montenegro is forced to import so-called crossbred wool (26 - 30 microns).

Our research evidence based on similar studies Kljajić et al [30] and "Strategy of development of agriculture and rural areas in Montenegro" by the Ministry of Agriculture and Rural Development of the Government of Montenegro [1], indicates a SWOT analysis which is used to determine the positive and negative factors affecting the achievement of strategic decisions for the development of agriculture in Montenegro. This method helps to establish a balance between internal capabilities and external opportunities or indicates a potential strengths, weaknesses, opportunities and threats of agriculture development of Montenegro. Therefore, according to the "Strategy for development of agriculture and rural areas in Montenegro" [1] in benefits by the SWOT analysis include: 1) favorable climate for many types of production, 2) High quality, condition and soil fertility, 3) Low level of soil pollution and nature thanks to low utilization of fertilizers and pesticides, 4) The diversity of biodiversity and natural beauty, 5) A tradition in the production and consumption of food as a cultural heritage, 6) Production of typical products such as lamb, ham from Njeguši, cheese from Pljevlja, cheese from Kolašin..., 7) Indigenous varieties in various sectors (olives, wine, livestock), 8) Good conditions for organic farming (production) and 9) Available land resources for expanded production. Disadvantages: 1) Fragmented holdings, 2) small volume of production, 3) Low utilization of modern technology and inadequate production facilities, 4) Poor and often outdated machinery, 5) High cost of inputs and lack of food for the animals, 7) Non-standardized products in certain sectors, 8) Poor cooperation among farmers, 9) Weak promotion and marketing, 9) Poor integration of the value chain, 10) Insufficient implementation of scientific research activities, 11) A set purchase system of raw milk, 12) Lack of storage capacities, 13) Poor rural infrastructure, 14) unfavorable age structure of producers, 15) Few links with the tourism sector, 16) still underdeveloped institutional capacity to implement projects, 17) Seasonal production, 18) Lack of approved facilities for the production of meat in the EU list and 19) Lack of skilled workers. Chances in the development of agriculture are: 1) Increasing demand in the domestic market as a result of general economic growth and the fact that people prefer domestic products, 2) Growth of the tourism sector, 3) Increase in the market for organic production, 4) The increasing demand for highly superior in quality products, 5) The availability of

\footnotetext{
${ }^{3}$ The variables and their symbols used in the formula: G - bovine animals, S - Pig, O-Sheep, K-Goat, Ko-Horses.
} 
government and EU assistance, 6) Positive international market trends, including the Middle East market, 7) low level of education and lack of knowledge of farmers, including good agricultural practices and environmental practices and 8 ) Poor knowledge of the process of processing on farms. Threats in the SWOT analysis are reflected through: 1) high dependence on imports, 2) Unfair competition, 3) illegal marketing of products, 4) Inadequate implementation of the measures and laws concerning environmental protection, 5) Low price competitiveness due to high input costs and low production volume, 6) lack of awareness of the public about the benefits of local products and 7) Difficult access to finance for farmers (loans). These trends, SWOT analysis provides a comprehensive view, perspectives, and limitations in the development of agriculture in Montenegro.

According to Ćetković [27] in Montenegro in 2003 registered 23 agricultural and agroindustrial enterprises and 30 agricultural cooperatives in which employs 270 workers, which in basic production are 11.579 hectares of arable land, processing facilities, organizational and personnel structure, which represents a significant potential of Montenegro in the development of modern agricultural production. The project visual marking of Montenegrin products, "Good from Montenegro" Chamber of Commerce of Montenegro began in September 2008. So far, the right to use the trademark "Good from Montenegro" obtain 74 products 14 Montenegrin producers. It is based on the results of the analysis of the Chamber of Commerce trade exchange of Montenegro with foreign countries, which recorded large, continuous and growing foreign trade deficit in the exchange of goods and services. Registration of a collective trademark "Good from Montenegro", and the entire work (analysis and campaign), Chamber of Commerce of Montenegro is implementing in order to achieve the following effects: promoting local resources and encouraging their use, development of domestic production, increase exports, new investments, new jobs, strengthening the identity States through the promotion of traditional values (products and services) in tourist facilities and general economic and social development of Montenegro [31]. However, the distribution of products with organic certification in the market of Montenegro is not enough, whether it is about the offer of fresh or processed products, which is strengthened by the fact of more and more frequent imports of these products into our market. Since there is often a lack of storage space, the products are only available during the peak season, when manufacturers flood the market. Sorting is done every other farmer and usually the size rarely according to quality. All this leads to the impairment of these products and reducing competitiveness. Also, when it comes to exports, it is mainly related to semi-finished products with a lower aggregation of values in our producers and processors. The market lacks a large number of ingredients, additives and auxiliary substances used in the processing of raw materials obtained by methods of organic production and necessary for the successful finalization of the product. Therefore, cluster processing and storage of organic food in its priority research projects highlights just above problems with the aim of raising the competitiveness of domestic production and processing to a higher level, thus contributing to the overall development of this sector [32].

According to Gulan [26] milling industry has a capacity that is optimum use can meet over $80 \%$, instead of $35 \%$ of the needs of Montenegro. Among the major subjects of are milling industry we recommend: " Žitopromet", "Montemlin Šajo" from Spuž, Mills"Muharem Asović " and "Abonus' 'from Nikšić. Significant capacity possessed by feed mills ABS and Koper from Nikšić and fodder in Spuž. Existing capacities in the dairy industry is not fully used, since processing industries may absorb and process (currently processed 20-25 million liters), between 55 and 60 million liters of milk per year and to cover the existing deficit in the supply of domestic milk market and dairy products. In recent years, the construction and expansion of the capacity of a large number of private companies and the construction of the dairy "Zora" in Berane significantly increased not only the capacity but significantly expanded and enhanced its product range: for the first time produced UHT milk, butter, different kinds of yogurt, as well as wider range of cheeses (fresh and creamy cheese ...). Slaughter industry in Montenegro has the capacity sufficient to meet domestic demand for meat products, as well as to offer significant amounts of product for export. Among the most significant capacity slaughterhouse industry group consisting of Meat 
Industry”Goranović”- Nikšić, „Pantomarket Bijela“ - Herceg Novi, „Mesopromet“ - Bijelo Polje, „Trojica“ - Pljevlja, „Gradina Company“ - Rožaje, „Niksen Trade“- Kotor (greenroom), „Martex“Cetinje (greenroom). Existing capacities for processing fruit and vegetables currently do not meet the current demand. This problem could be overcome, completion and distribution center with a drive for fruit and vegetables (AD "Plodovi" CG). Food industry Montenegro also has significant capacities in other sectors: industry, beer and soft drinks, alcoholic and non-alcoholic drinks, bakery, confectionery, ice cream production ... Among the most important facilities of the food industry in this case are: "D.O.O.Pirella" - Podgorica, factory of non-alcoholic drinks Mediterano spices - Danilovgrad, production of spices and olive oil "OLIOPROM" - Bar, olive oil production "L' Ars Montenegro" - Podgorica, production and processing of fruits and vegetables - healthy ecological fruits from the area "Meduza - Koop" - Bijelo Polje, processing and preserving of fruit (raspberry) "Plantaže AD " - Podgorica, production of premium wines and grape brandy "AD Trebjesa" - Nikšić, Industry beers and juices "Sjekloća" - Bar, production of grapes and grape products (wine program) "Rada" - Bijelo Polje, production and sales of natural mineral water "Gorska" - Šavnik, production and sales of high-quality spring water from Durmitor "Aleksandrija" - Herceg Novi, production of bread, rolls, pastries "Inpek" - Podgorica, "AD Montenegro Koop"Danilovgrad, processing and selling coffee, spices, confectionery, sweets "Don-Ze" - Podgorica, production of ice cream "Lar's d.o.o."- Podgorica ...[26].

Bearing in mind the production-economic basis in question, according to Ćetković [27], agricultural and industrial enterprises in the process of structural change needs to develop in the following directions: create a production structure that will have a specific quality and a recognizable brand products, using natural and market advantages; change the ownership structure of assets and capital with which companies have and introduce modern management system known in countries with highly developed economies; released the technological and economic redundant laborers; create a model market performance of companies in which the quality, competitiveness, stylish design and marketing to be the backbone of business policy; create professional-highly specialized staff who will be able to transfer modern knowledge into practice and creatively incorporate these characteristics of food products which will make specific, rare and commercially attractive.

\section{CONCLUSION}

Our research evidence based on similar surveys ACCESS - program for the development of the private sector in Serbia [32], Lungu [33], Stanković [34], Pacheco [35], Lemaire et al [36], Mahesh [37], points to following conclusions:

1. A favorable climate for the production of different varieties of plants, well preserved natural environment, including high-quality, preserved and fertile land, the low level of pollution Thanks to the low use of fertilizers and pesticides, are elements that contribute to the development of agriculture,

2. Basic characteristics of agricultural production in Montenegro, which are reflected through: low average yields as compared to the EU, and in comparison with the period of the eighties years the last century; a large number of small producers who produce for their own needs with minimal investment; underdeveloped market rural credit, both because of low demand, but also due to weaker supply; great variability in crop production; a drop in production of livestock products; failure to the create significant improvements in producing and selling vegetables; decline in industrial production; stagnation in milk production, but also progress in the processing of milk and reduced rate of plant and animal production in total agricultural production following the establishment of market economy[38],

3. In order to get an adequate picture of agricultural land in Montenegro in 2012, we applied the method alternate divisor in system $6 / 6$ and found the following direction: $\mathrm{O}_{1} \mathrm{~L}_{2} \mathrm{P}_{3}$ balanced grazing direction use agricultural land with a greater share of meadows and plowed land, while in the structure of arable areas include direction: $\mathrm{P}_{02} \mathrm{~N}_{2} \breve{Z}_{1} \mathrm{Sk}_{1}$ direction with equal participation of vegetables, uncultivated land and participation of grain and fodder crops, 
4. In addition to its importance and favorable natural conditions of livestock in Montenegro is in deep crisis. This is indicated by the use of methods of alternating divisor in system 6/6: $0_{3}$ $\mathrm{G}_{2} \mathrm{~K}_{1}$ Direction with equal participation of sheep farming with higher participation bovine animals and goat participation,

5. SWOT analysis provides a comprehensive view, perspectives, and limitations in the development of agriculture in Montenegro. The process of general and qualitative transformation of agriculture will be relatively very slow and time consuming. Therefore, you should work on it patiently, but persistently and continuously,

6. The food industry is a significant potential of Montenegro in the development of modern agricultural production. For example, the slaughter industry has the capacity sufficient to meet domestic demand for meat products, as well as to offer significant amounts of product for export. Milling industry has a capacity that is optimum use can meet over $80 \%$, instead of $35 \%$ of the needs of Montenegro ... However, the distribution of products with organic certification in the market of Montenegro is not enough, whether it is about the offer of fresh or processed products, which is strengthened by the fact of more and more frequent imports of these products into our market. Since there is often a lack of storage space, the products are only available during the peak season, when manufacturers flood the market.

The paradigm of competitiveness viewed agriculture as a competitive economic sector, with average or even above-average income, successful, both on the domestic and international market. According to this paradigm, agriculture should operate in terms of market laws, without undue state interference. The paradigm of multi functionality agriculture is perceived as integral part of the rural area, which is next to the market and provides certain non-market goods, which refers to the protection of the environment and landscape, maintaining the family business, stimulating rural development, preservation of cultural and historical heritage, improving the conditions of livestock...The paradigm of globalized production puts agriculture in a global framework to insist on the quality and safety standards due to market-oriented production [39].

\section{References}

[1] The Government of Montenegro, Ministry of Agriculture and Rural Development Strategy for Agriculture and Rural Areas (Draft), Podgorica,2014.

[2] S. Šljukić, Changes in the social structure and the role of the peasantry, 71-84,2014, Information to: http://www.dioserbia.nb.rs (22.09 2015).

[3] A.D.Anufrijev, G. Dašić, Comparative advantages of Serbian agriculture and sustainable development, Socioeconomica. 1(2)(2012) 143-154.

[4] R.Stefanović, S. Obradović, Z. Broćić, Perspektive i razvojni izazovi preduzetništva u poljoprivredno-prehrambenom sektoru Republike Srbije, Učenje za poduzetništvo. 2(2)(2012) 371-380.

[5] E. Sima, Impact of organic farming promotion upon the sustainable rural development, Agricultural Economics and Rural Development, New Series. Year VI(2)(2009)217-233.

[6] I.Kostrovicki, Typologia rolnictwa, Preglad Geograficzny. 161 (4)(1969)599-621.

[7] I.Kostrovicki, Some Methods of determining land use and agricultural orientations as used in the Polish land utilization and typological studies, Geographia Polonica, Book 18, Poland,1970.

[8] B.Jaćimović, Methodology agro-geographic study of typologies of agriculture”, Proceedings of Institute of Geography Faculty of Science. 23(1976) 94-99.

[9] W.Tyszkiewicz, Przemiany struktury przestrzennej rolnictwa Polski 1950-1970, Prace Geograficzne. 126(1978) 15-54.

[10] G.Rajović,J. Bulatović, Agricultural Areas and Forests: The Case Regions Polimlje-Ibar, Journal of Agriculture and Sustainability. 2(2)(2013)178-195. 
[11] G.Rajović,J. Bulatović, Structural changes utilization agricultural land and plant production: the case northeastern Montenegro, International Letters of Social and Humanistic Sciences. 3(2013) 10-20.

[12] G. Rajović, J. Bulatović, Structural changes in livestock production: the case northeastern Montenegro, International Letters of Social and Humanistic Sciences. 3(2013)37-45.

[13] G. Rajović, J. Bulatović, Status and perspectives plant production: the case regions PolimljeIbar, Annals of Plant Sciences. 2(7)(2013).

[14] G. Rajović, J. Bulatović, Geographical View on Agricultural Land and Structural Changes Plant Production Region POLIMLJE - IBAR, International Research Journal of Life Sciences. 1(2)(2013) 1-18.

[15] G.Rajović, J. Bulatović, Status and Perspectives Livestock Production: The Case Region Polimlje-Ibar, International Letters of Natural Sciences. 6(2014) 57-68.

[16] G.Rajović, J. Bulatović, Structural changes livestock production: Case study region PolimljeIbar, Vestnik OrelGAU. 1(46)(2014) 3-13.

[17] G. Rajović, Structure and trends of soil usage in Montenegro, Natura Montenegrina. $9(2)(2010) 205-214$.

[18] G. Rajović, J. Bulatović, Geographical View on Agricultural Land and Structural Changes Plant Production Montenegro, Scientific Electronic Archives. 5(1)(2014)5-21.

[19] G. Rajović, J. Bulatović, Structural Changes in Livestock Production: A Case Study in Montenegro, International Letters of Social and Humanistic Sciences. 15(2)(2015) 125-137.

[20] G.Rajović, J. Bulatović, Some geographical aspects of sustainable development with view on Montenegro: a review, International Letters of Social and Humanistic Sciences. 1(2)(2015) 98-109.

[21] G. Rajović, J. Bulatović, Some Geographical Aspects of Rural Development with view of Montenegro: A Review, Journal of Economic and Social Thought. 2(1)(2015) 3-15.

[22] G.Rajović,J. Bulatović, Some Geographical Aspects of sustainable development of agriculture with view on Montenegro: a review, World Scientific News. 8(2015), 82-93.

[23] G.Rajović, J.Bulatović, Structural changes of plant production in Montenegro (2003-2012): a review, World Scientific News. 12(2015) 111-124.

[24] G. Rajović, J. Bulatović, Structural changes in livestock production in Montenegro (2004 2012): a rewiew, European Geographical Studies.7(3)(2015) 128-136.

[25] Statistical Office of Montenegro, Department of Agriculture statistics, Podgorica,2013.

[26] B. Gulan, Agrarian sector Montenegrin market for 620.000 consumers, 2006, Agropress, Information to: http://www.agropress ( 21.09 2015).

[27] B. Ćetković, The possibility of the development of primary grains in Montenegro, 2012, Information to: http://www.avjetodavna.org (26.09 2015).

[28] B. Gulan, Condition and potential in food production in Serbia 2013, 2014, Information to: http://www.makroekonomija.org ( 24.09 2015).

[29] R. Škorić, Poultry in Serbia, 2006, Information to: http://www.poljoberza.ne (24.10 2014).

[30] N. Kljajić,S.Arsić,M.Savić, Livestock as a development opportunity for Serbia, 2011, Information to: http://www.agroekonomija.wordpress.com (23.09 2015).

[31] Chamber of Commerce of Montenegro, Good from Montenegro, Montenegro Chamber of Commerce, Podgorica, 2013. 
[32] National research agenda for the sector of organic agriculture, ACCESS - Program for private sector development in Serbia, Belgrade: GIZ-Deutsche Gesellschaft für Internationale Zusammenarbeit GmbH, 2013.

[33] J.C.N.Lungu, Mixed crop-livestock production systems of smallholder farmers in sub-humid and semi-arid areas of Zambia, field evaluation of animal feed supplementation packages.(2002) 135.

[34] M.Stanković, Agrarna politika Srbije i Zajednička poljoprivredna Politika, ̌̌kola biznisa.3(2012) 65-72.

[35] A.R.Pacheco, R.D.Q. Chaves, C.M.L. Nicoli, Integration of crops, livestock, and forestry: A system of production for the Brazilian Cerrados, Eco-efficiency: from vision to reality'.(Ed. $K G$ Cassman) Ch, 4(2012).

[36] G.Lemaire, A. Franzluebbers, P.C. de Faccio Carvalho, B. Dedieu, Integrated crop-livestock systems: Strategies to achieve synergy between agricultural production and environmental quality, Agriculture, Ecosystems \& Environment. 190(2014) 4-8.

[37] M.S.Mahesh, M. Mohini, Crop Residues for Sustainable Livestock Production, J Adv Dairy Res. 2(2014) e108.

[38] G. Rajović, Morphology and opportunities agricultural valorization: the case northeastern Montenegro, Hyperion International Journal of Econophysics \& New Economy. 6(2)(2013) 301-315.

[39] Globalization and Sustainable Development of Agriculture, Regional Chamber of Commerce Pančevo, Bilten 75, Information to: http://www.rpkpancevo.com (25.09 2015). 